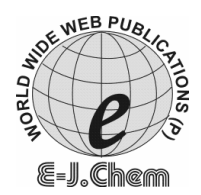

\title{
Groundwater Quality of Southeastern Brazzaville, Congo
}

\author{
MATINI LAURENT and MOUTOU JOSEPH MARIE
}

\author{
Department of Exact Sciences, \\ E.N.S., Marien NGOUABI University, B.P 69 Brazzaville, Congo. \\ matinilaurent@yahoo.fr
}

Received 2 October 2009; Accepted 1 December 2009

\begin{abstract}
The groundwater in southeastern Brazzaville (Congo) was analyzed for their fluoride contents and others related parameters in rainy season. The fluoride contents in water samples (wells and spring) can be gather in three classes in the study area: low, optimal, high. Fluoride concentration in water samples presents a low significant correlation with $\mathrm{Ca}^{2+}$. This suggests that fluoride in the groundwater come from fluoride-bearing minerals such as $\mathrm{CaF}_{2}$ (fluorite). Maps were drawn to show the geographical distribution of $\mathrm{EC}, \mathrm{Ca}^{2+}, \mathrm{Mg}^{2+}$ and $\mathrm{F}$. Factor analysis and cluster analysis were applied to the dataset. Factor analysis resulted in four factors explained $76.90 \%$ of the total groundwater quality variance. Factor 1 (hardness of the groundwater) includes total hardness, the concentration of $\mathrm{K}^{+}, \mathrm{Ca}^{2+}$ and $\mathrm{pH}$. Factor 2 (low mineralization of the groundwater) includes concentrations of TDS, $\mathrm{Cl}^{-}, \mathrm{SO}_{4}{ }^{2-}$ and EC. Factor 3 (anthropogenic activities with the impact of agricultural fertilizers, farming activities, domestic wastewater, septic tanks) includes concentrations of $\mathrm{Na}^{+}$and $\mathrm{NO}_{3}^{-}$. Factor 4 (weathering of calcium minerals) includes concentrations of F- For cluster analysis, Ward's method and the Euclidean distance were used. The findings of the cluster analysis are presented in the form of dendrogram of the well water sites (cases). The discriminating parameters between clusters have been highlighted from the Student test. In majority, they are in accordance with those highlighted by factor analysis.
\end{abstract}

Keywords: Fluoride, Groundwater, Sandstone aquifer, Factor analysis, $t$-Test.

\section{Introduction}

Fluoride is of interest, because of its effects on human health. Even small quantity of fluoride $(<0.7 \mathrm{mg} / \mathrm{L})$ has beneficial effects to the teeth by hardening the enamel and reducing the incidence of dental caries ${ }^{1}$. Excessive intake of fluoride $(>1.5 \mathrm{mg} / \mathrm{L})$ results in dental and skeletal fluorosis ${ }^{2}$. Unlike many others elements, a large quantity of fluoride is ingested from drinking water and food. Many studies have reported that fluoride is one of the most undesired elements present in the underground water extracted for drinking ${ }^{3-5}$. 
Fluoride build-up in water is controlled by many factors like aquifer geology, contact times with fluoride-bearing minerals, agricultural fertilizers and climate. Fluoride mainly occurs in groundwater through fluoride-rich minerals, such as fluorite $\left(\mathrm{CaF}_{2}\right)$, fluorapatite $\mathrm{Ca}_{5} \mathrm{~F}\left(\mathrm{PO}_{4}\right)_{3}$, apatite $\mathrm{Ca}_{5}\left(\mathrm{PO}_{4}\right)_{3}(\mathrm{~F}, \mathrm{OH}, \mathrm{Cl})$. It derives from dissolution of these minerals in the rocks and soils through which water interacts.

The present study has been designed for the first time on the concentration of fluoride in groundwater in Southeastern Brazzaville, Congo, which provides baseline data for taking appropriate management measures to reduce the intensity of health disorders.

\section{The study area}

The study area is located between $15^{\circ} 13^{\prime} 53^{\prime \prime}$ - $15^{\circ} 14^{\prime} 10^{\prime \prime}$ East longitude and $4^{\circ} 15^{\prime} 7.2^{\prime \prime}$ to $4^{\circ} 15^{\prime} 28.8^{\prime \prime}$ South latitude. The area is in the equatorial climate zone, with two seasons: rainy season (October to May) and dry season (June to September). Temperature in rainy season varies from $25^{\circ} \mathrm{C}$ to $36^{\circ} \mathrm{C}$, while it is between $18{ }^{\circ} \mathrm{C}$ and $24{ }^{\circ} \mathrm{C}$ in dry season. The mean annual rainfall is $1470 \mathrm{~mm}$. The vegetation is of savanna type (Loutetia demeusi) and presents a formation to sparse gramineous carpet with a shrubby layer of hymenocardia acida. The soils of the area are sandy and have been derived from Tertiary Silicate Sandstones of the Inkisi Serial. They are ferralitic and acid. Aquifer is shallow. Generally, the depth of wells does not exceed $2 \mathrm{~m}$. The main natural recharge to groundwater is from precipitation (rainfall). Farming activities are present around some well water sites and also agricultural activities near the River Mfilou.

\section{Experimental}

Twenty seven samples of wells water and one sample of spring water were collected in three times in rainy season (from March 25 to April 5, 2007) from the study area. They were analyzed for $\mathrm{pH}$, electrical conductivity (EC), total dissolved solids (TDS), total hardness ( $\mathrm{TH}$ as $\mathrm{CaCO}_{3}$ ), $\mathrm{Ca}^{2+}, \mathrm{Mg}^{2+}, \mathrm{K}^{+}, \mathrm{Cl}^{-}, \mathrm{SO}_{4}{ }^{2-}, \mathrm{NO}_{3}{ }^{-}, \mathrm{HCO}_{3}{ }^{-}$and following standard methods ${ }^{6}$. The ratio $\mathrm{Ca}^{2+} / \mathrm{Mg}^{2+}$ was also computed for all the groundwater samples. STATISTICA 7.1 software was used to perform factor and cluster analyses. Factor analysis was used to understand the correlation structure of collected data and identified most important factors contributing the data structure ${ }^{7}$. The data were standardized to produce a normal distribution of all variables ${ }^{8}$, whose mean and variance were set to zero and one respectively. The factor extraction was performed, using the method of principal components. Kaiser criterion", which retains only the factors with eigenvalues greater than 1, was applied. The proportion of variance in all the groundwater parameters accounted for each factor was obtained by dividing the factor's eigenvalue by the number of parameters. Interpretation of groundwater quality was facilitated, using the varimax rotation, which is a standard rotation method. Cluster analysis is also another data reduction method ${ }^{10}$ that was used to classify entities or objects, with similar properties into groups called clusters. Objects within the clusters are similar, while objects in different clusters are dissimilar. This exploratory method enables to discover the data structure not only among observations, but also among variables. In this study, the Ward's clustering method and the Euclidean distance was used as a similarity measure.

\section{Results and Discussion}

Table 1 presents the chemical composition of groundwater samples in the study area. It is observed that the $\mathrm{pH}$ in all the groundwater samples ranges from 3.85 to 6.08 , with a mean of 5.22, indicating an acidic environment. The $\mathrm{pH}$ values are below the prescribed limits of 6.5-8.5 for drinking. The results show that electrical conductivity is varied between $75 \mu \mathrm{S} / \mathrm{cm}$ and $431.20 \mu \mathrm{S} / \mathrm{cm}$, with a mean of $235.51 \mu \mathrm{S} / \mathrm{cm}$ (at $25^{\circ} \mathrm{C}$ ), indicating the 
groundwater is slightly mineralized (Table 1). Wells, P6 and P14 located in northwestern and well P23 located in southern parts of the study area, presented in Figure 1, show the higher electrical conductivity value, which is attributable to the influence of domestic wastewater.

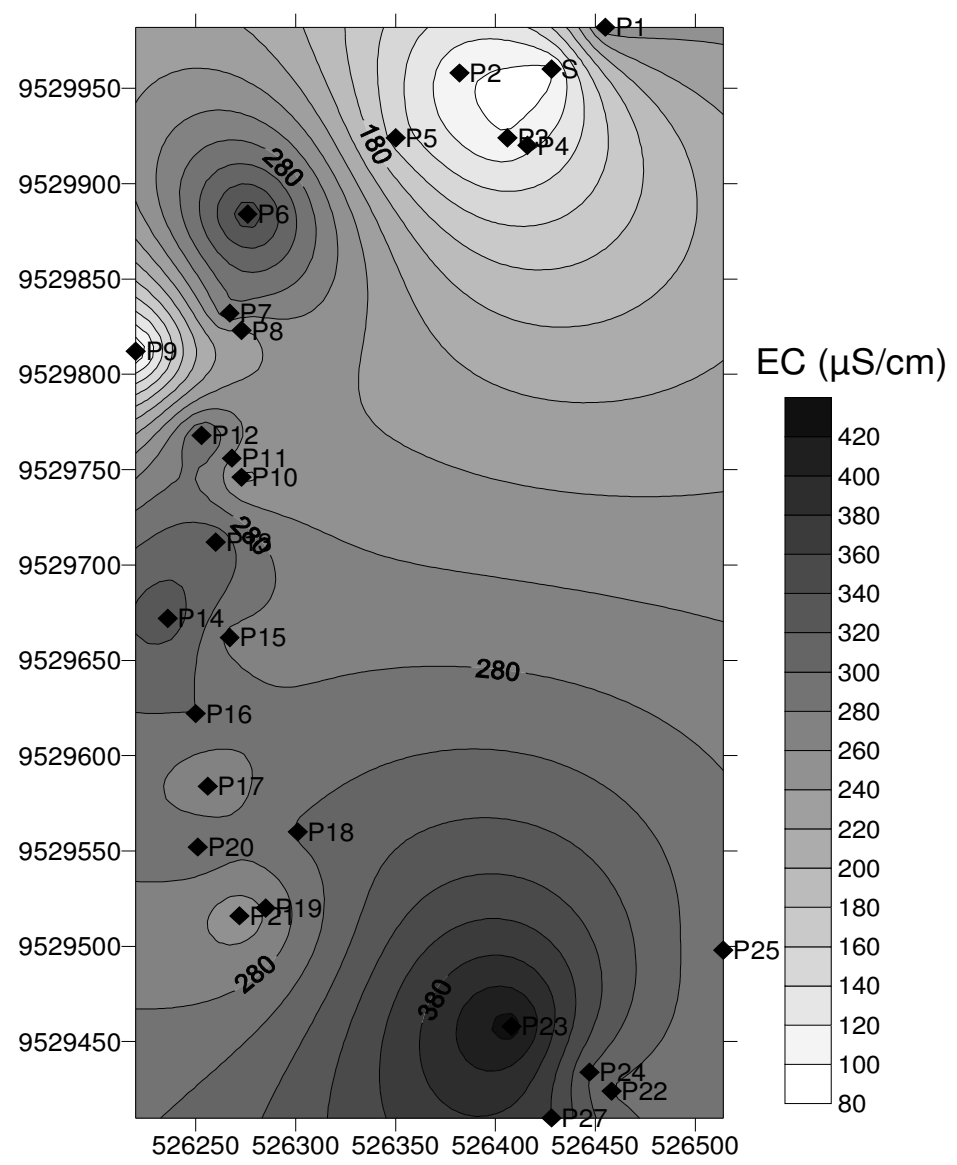

Figure 1. Contour map of EC (in $\mu \mathrm{S} / \mathrm{cm}$ ) in the wells water and spring water.

The TDS, which is an indicative parameter to assess the degree of water quality, is below $230 \mathrm{mg} / \mathrm{L}$ in the water samples. This is, within the recommended limit of 500 $\mathrm{mg} / \mathrm{L}$ for drinking purpose ${ }^{2}$. The TA ranges from 5 to $84.98 \mathrm{mg} / \mathrm{L}$ (mean of $26.21 \mathrm{mg} / \mathrm{L}$ ). The TH in the groundwater samples is in the range of 5 to $60 \mathrm{mg} / \mathrm{L}$ (mean of 29.32 $\mathrm{mg} / \mathrm{L}$ ) and indicates that the water belong to the soft category ${ }^{11}$. The concentration $(\mathrm{mg} / \mathrm{L})$ of calcium, magnesium, sodium, potassium, chloride, sulfate and nitrate is in the range of 4 to 30,5 to $14,1.13$ to $36.25,2$ to $12,5.4$ to $44.0,2$ to 11 , and 0.25 to 23.20 $\mathrm{mg} / \mathrm{L}$ with a mean of $16.03,8.5,10.81,5.28,20.24,7.79$ and $1.86 \mathrm{mg} / \mathrm{L}$, respectively. Compared to $\mathrm{WHO}^{2}$, the concentration of the parameters quoted above are below the safe limit of 100, 150, 200, 200, 250, 200 and $50 \mathrm{mg} / \mathrm{L}$ for drinking, respectively. Since the chloride-rich minerals are not found in the study area, the higher concentrations of chloride in the groundwater could be caused by pollution sources such of domestic wastewater and septic tanks. 
Table 1. Hydrochemical parameters of groundwaters in the study area.

\begin{tabular}{|c|c|c|c|c|c|c|c|c|c|c|c|c|c|c|c|}
\hline Code & $\mathrm{pH}$ & EC & TDS & TA & $\mathrm{TH}$ & $\mathrm{Ca}^{2+}$ & $\mathrm{Mg}^{2+}$ & $\mathrm{Na}$ & $\mathrm{K}^{+}$ & $\mathrm{Cl}^{-}$ & $\mathrm{SO}_{4}{ }^{2-}$ & $\mathrm{HCO}_{3}^{-}$ & $\mathrm{F}^{-}$ & $\mathrm{NO}_{3}^{-}$ & $\mathrm{Ca}^{2+} / \mathrm{Mg}^{2+}$ \\
\hline$S$ & 3.90 & 93.92 & 49.88 & 40.00 & 5 & 4 & 12 & 2.53 & 3.2 & 19.53 & 2 & 48.80 & 0.42 & 0.56 & 0.20 \\
\hline P1 & 3.98 & 251.20 & 133.00 & 5.00 & 20 & 12 & 10 & 9.84 & 5.8 & 32.23 & 7 & 6.10 & 0.29 & 1.08 & 0.72 \\
\hline P2 & 4.00 & 104.92 & 55.54 & 5.00 & 10 & 8 & 12 & 17.43 & 2.0 & 18.10 & 4 & 6.10 & 0.19 & 3.90 & 0.40 \\
\hline P3 & 4.22 & 100.84 & 53.46 & 30.00 & 15 & 6 & 13 & 8.49 & 3.1 & 12.35 & 7 & 36.60 & 0.37 & 0.25 & 0.20 \\
\hline P4 & 5.21 & 116.44 & 61.96 & 15.00 & 30 & 8 & 14 & 18.47 & 4.1 & 19.89 & 10 & 18.30 & 0.58 & 0.66 & 0.34 \\
\hline P5 & 6.05 & 151.54 & 80.50 & 50.00 & 60 & 22 & 11 & 16.42 & 7.0 & 10.43 & 9 & 61.00 & 0.66 & 0.84 & 1.20 \\
\hline P6 & 5.69 & 355.80 & 190.00 & 30.00 & 55 & 22 & 12 & 27.65 & 10.5 & 14.98 & 7 & 36.60 & 0.50 & 23.20 & 1.10 \\
\hline P7 & 5.78 & 277.20 & 147.60 & 23.00 & 50 & 21 & 10 & 25.35 & 8.2 & 15.46 & 5 & 28.06 & 0.47 & 1.20 & 1.25 \\
\hline P8 & 5.55 & 232.60 & 123.20 & 13.00 & 15 & 14 & 7 & 4.28 & 4.9 & 29.00 & 7 & 15.86 & 0.40 & 0.84 & 1.20 \\
\hline P9 & 5.62 & 75.88 & 40.40 & 84.98 & 40 & 12 & 11 & 3.63 & 11.0 & 5.40 & 5 & 103.70 & 0.38 & 2.30 & 0.66 \\
\hline P10 & 5.45 & 234.20 & 124.80 & 21.00 & 49 & 20 & 9 & 36.25 & 9.0 & 15.11 & 7 & 25.62 & 0.40 & 0.99 & 1.33 \\
\hline P11 & 5.98 & 258.20 & 137.60 & 70.00 & 45 & 30 & 12 & 8.28 & 12.0 & 29.83 & 10 & 85.40 & 0.37 & 0.96 & 1.52 \\
\hline $\mathrm{P} 12$ & 5.15 & 304.60 & 161.80 & 65.00 & 40 & 27 & 10 & 9.57 & 4.0 & 14.27 & 8 & 79.30 & 2.90 & 0.87 & 1.62 \\
\hline $\mathrm{P} 13$ & 5.53 & 315.20 & 167.60 & 50.00 & 38 & 16 & 8 & 1.13 & 3.9 & 13.19 & 7 & 61.00 & 0.32 & 0.92 & 1.20 \\
\hline P14 & 5.09 & 333.80 & 177.40 & 47.00 & 37 & 20 & 9 & 5.08 & 4.0 & 17.86 & 9 & 57.34 & 0.37 & 1.00 & 1.33 \\
\hline P15 & 4.58 & 272.80 & 145.00 & 51.00 & 29 & 17 & 7 & 2.09 & 3.4 & 16.54 & 6 & 62.22 & 0.31 & 1.07 & 1.47 \\
\hline P16 & 3.85 & 300.20 & 159.40 & 5.00 & 20 & 14 & 6 & 13.98 & 4.7 & 14.39 & 10 & 6.10 & 0.29 & 1.10 & 1.40 \\
\hline P17 & 5.74 & 261.80 & 164.40 & 8.00 & 30 & 15 & 5 & 12.93 & 4.5 & 11.75 & 11 & 9.76 & 0.21 & 1.09 & 1.81 \\
\hline P18 & 4.41 & 302.80 & 161.00 & 10.00 & 28 & 17 & 5 & 14.42 & 4.0 & 11.87 & 10 & 12.20 & 0.23 & 1.10 & 2.04 \\
\hline P19 & 5.71 & 261.80 & 139.40 & 12.00 & 31 & 16 & 5 & 12.21 & 3.9 & 12.71 & 9 & 14.64 & 0.21 & 2.00 & 1.92 \\
\hline P20 & 5.12 & 297.20 & 157.80 & 11.00 & 27 & 18 & 6 & 10.26 & 4.0 & 24.50 & 7 & 13.42 & 0.22 & 0.84 & 1.81 \\
\hline $\mathrm{P} 21$ & 5.69 & 245.60 & 131.00 & 10.00 & 20 & 15 & 7 & 7.45 & 4.0 & 26.50 & 8 & 12.20 & 0.16 & 0.66 & 1.29 \\
\hline P22 & 5.37 & 299.00 & 158.80 & 13.00 & 30 & 17 & 6 & 5.73 & 5.0 & 27.00 & 10 & 15.86 & 0.11 & 0.85 & 1.70 \\
\hline P23 & 5.96 & 431.20 & 229.80 & 12.00 & 22 & 16 & 5 & 8.05 & 3.9 & 44.00 & 9 & 14.64 & 0.80 & 0.70 & 1.92 \\
\hline P24 & 5.79 & 318.60 & 169.40 & 14.00 & 29 & 18 & 6 & 8.56 & 4.0 & 25.00 & 7 & 17.08 & 0.70 & 0.82 & 1.80 \\
\hline P25 & 5.20 & 284.60 & 151.40 & 13.00 & 15 & 16 & 7 & 6.42 & 4.1 & 27.00 & 9 & 15.86 & 0.60 & 0.70 & 1.37 \\
\hline P26 & 5.60 & 255.60 & 135.40 & 12.00 & 14 & 15 & 5 & 1.29 & 4.7 & 31.80 & 10 & 14.64 & 0.50 & 0.89 & 1.81 \\
\hline P27 & 6.09 & 360.80 & 193.60 & 14.00 & 17 & 13 & 8 & 4.83 & 5.0 & 26.00 & 8 & 17.08 & 0.70 & 0.66 & 0.98 \\
\hline
\end{tabular}


The $\mathrm{Ca}^{2+} / \mathrm{Mg}^{2+}$ ratio is divided the groundwater quality as less than 1 and more than 1 (Table 1). The water observed from the location of $\mathrm{S}, \mathrm{P} 1, \mathrm{P} 2, \mathrm{P} 3$ and $\mathrm{P} 4$ have $\mathrm{Ca}^{2+} / \mathrm{Mg}^{2+}$ ratio less than 1, while the water found from the locations $\mathrm{P} 5$ to $\mathrm{P} 27$ have $\mathrm{Ca}^{2+} / \mathrm{Mg}^{2+}$ ratio more than 1 . The $\mathrm{Ca}^{2+} / \mathrm{Mg}^{2+}$ ratio less than 1 indicates the weathering process of calcium minerals whereas the $\mathrm{Ca}^{2+} / \mathrm{Mg}^{2+}$ ratio more than 1 indicates the dissolution of more magnesium minerals. The groundwater samples have been also characterized by $\mathrm{HCO}_{3}{ }^{-} / \mathrm{Ca}^{2+}$ ratio, which vary between 0.17 and 0.96 in $75 \%$ of the total groundwater samples. However, this ratio is high than 1 in $25 \%$ of the total groundwater samples. This suggests the importance of the alkalinity in the groundwater.

Table 2 presents the summary of chemical composition of groundwater. All the groundwater parameters have a low coefficient of variance, except nitrate, fluoride and bicarbonate of which the value was $2.24,1.02$ and 0.83 , respectively. Thus the nitrate, fluoride and bicarbonate ions show a great variability of their concentrations in the groundwater samples.

Table 2. Summary of chemical composition of groundwater in the study area.

\begin{tabular}{lccccc}
\hline \multicolumn{1}{c}{ Parameter } & Min & Max & Mean & SD & $\mathrm{CV}$ \\
\hline $\mathrm{pH}, \mathrm{units}$ & 3.85 & 6.08 & 5.22 & 0.13 & 0.13 \\
$\mathrm{EC}, \mu \mathrm{S} / \mathrm{cm}$ & 75.88 & 431.20 & 253.51 & 16.81 & 0.34 \\
$\mathrm{TDS}, \mathrm{mg} / \mathrm{L}$ & 40.40 & 229.80 & 135.75 & 9.03 & 0.34 \\
Calcium, mg/L & 4.00 & 30.00 & 16.03 & 1.08 & 0.35 \\
Magnesium, mg/L & 5.00 & 14.00 & 8.50 & 0.53 & 0.32 \\
Sodium, mg/L & 1.13 & 36.25 & 10.81 & 8.20 & 0.76 \\
Potassium, mg/L & 2.00 & 12.00 & 5.28 & 0.48 & 0.47 \\
Chloride, mg/L & 5.40 & 44.00 & 20.24 & 1.63 & 0.42 \\
Sulphate, $\mathrm{mg} / \mathrm{L}$ & 2.00 & 11.00 & 7.79 & 0.39 & 0.26 \\
Bicarbonate, mg/L & 6.10 & 103.70 & 31.98 & 5.12 & 0.83 \\
Fluoride, mg/L & 0.11 & 2.90 & 0.49 & 0.10 & 1.02 \\
Nitrate, $\mathrm{mg} / \mathrm{L}$ & 0.25 & 23.20 & 1.86 & 0.80 & 2.24 \\
Total Alkalinity, mg/L CaCO & 5.00 & 84.98 & 26.21 & 21.79 & 0.83 \\
Total Hardness, mg/L CaCO ${ }_{3}$ & 5.00 & 60.00 & 29.32 & 2.65 & 0.47 \\
Ca $^{2+} / \mathrm{Mg}^{2+}$ & 0.20 & 2.04 & 1.27 & 0.10 & 0.41 \\
\hline \multicolumn{5}{c}{$S D=$ standard deviation, $C V=$ coefficient of variation. }
\end{tabular}

Fluoride content varies from 0.11 to $2.90 \mathrm{mg} / \mathrm{L}$, with a mean of $0.49 \mathrm{mg} / \mathrm{L}$. Maximum concentration of fluoride is observed at well site P12. About $86 \%$ of the total groundwater sampling sites have fluoride concentration less than $0.7 \mathrm{mg} / \mathrm{L}$. Fluoride concentration is ranged from $0.7 \mathrm{mg} / \mathrm{L}$ to $0.8 \mathrm{mg} / \mathrm{L}$ in $10.71 \%$ of the total groundwater samples. In $3.58 \%$ of the total water samples, it is greater than $1.5 \mathrm{mg} / \mathrm{L}$. The range $0.7-0.8 \mathrm{mg} / \mathrm{L}$ of fluoride content is considered as optimal limit for drinking according to $\mathrm{WHO}^{2}$. Only in one well site (P12), the fluoride content exceeds the optimal limit. The high concentrations of fluoride suggest a long contact time of water with aquifer material. Some studies suggest that the fluoride content in groundwater is correlated well with $\mathrm{pH}$ and alkaline environment ${ }^{12-13}$ and some studies ${ }^{14-15}$ suggest that the near-neutral $\mathrm{pH}$ and alkaline soils are favorable to increase the concentration of fluoride bearing minerals in the groundwater.

Table 3 presents the correlation among various parameters of groundwater in the study area. Electrical conductivity shows a positive correlation at $\mathrm{p}<0.05$, with $\mathrm{Ca}^{2+}(\mathrm{r}=0.54), \mathrm{Cl}^{-}(\mathrm{r}=0.41)$ and $\mathrm{SO}_{4}^{2-}(\mathrm{r}=0.42)$. The association of fluoride with calcium $(\mathrm{r}=0.38)$ and with magnesium $(\mathrm{r}=0.15)$ and with $\mathrm{pH}(\mathrm{r}=0.13)$ is less positive significant. The correlation between $\mathrm{Mg}$ and $\mathrm{HCO}_{3}{ }^{-}$ $(r=0.46)$ is more than that of correlation between $\mathrm{Ca}$ and $\mathrm{HCO}_{3}{ }^{-}(r=0.37)$, which supports the 
$\mathrm{Ca}^{2+} / \mathrm{Mg}^{2+}$ ratio. Calcium and magnesium could proceed from the weathering process of the minerals in the sandstone bedrock, such as fluoride-rich minerals and $\mathrm{MgCO}_{3}$. The correlation between fluoride and calcium indicates the weathering of calcium minerals as a dominant controlling mechanism for leaching of fluoride from the sources material in the groundwater.

Table 3. Correlation matrix for wells water parameters of rainy season.

\begin{tabular}{|c|c|c|c|c|c|c|c|c|c|c|c|c|c|c|c|}
\hline & $\mathrm{pH}$ & $\mathrm{EC}$ & TDS & TA & $\mathrm{TH}$ & $\mathrm{Ca}^{2+}$ & $\mathrm{Mg}^{2+}$ & $\mathrm{Na}^{+}$ & $\mathrm{K}^{+}$ & $\mathrm{Cl}^{-}$ & $\mathrm{SO}_{4}{ }^{2-}$ & $\mathrm{HCO}_{3}{ }^{-}$ & $\mathrm{F}$ & $\mathrm{NO}_{3}{ }^{-}$ & $\mathrm{Ca}^{2+} / \mathrm{Mg}^{2+}$ \\
\hline $\mathrm{pH}$ & 1.00 & 0.36 & 0.37 & 0.17 & 0.51 & 0.53 & -0.20 & 0.06 & 0.43 & 0.16 & 0.33 & 0.17 & 0.13 & 0.10 & 0.43 \\
\hline EC & & 1.00 & 1.00 & -0.24 & 0.15 & 0.54 & -0.62 & -0.03 & -0.03 & 0.41 & 0.42 & -0.24 & 0.17 & 0.17 & 0.73 \\
\hline TDS & & & 1.00 & -0.25 & 0.15 & 0.53 & -0.63 & -0.02 & -0.03 & 0.39 & 0.45 & -0.25 & 0.16 & 0.17 & 0.74 \\
\hline TA & & & & 1.00 & 0.50 & 0.37 & 0.46 & -0.22 & 0.47 & -0.39 & -0.23 & 1.00 & 0.35 & 0.04 & -0.18 \\
\hline TH & & & & & 1.00 & 0.72 & 0.23 & 0.53 & 0.68 & -0.42 & 0.15 & 0.50 & 0.18 & 0.35 & 0.23 \\
\hline $\mathrm{Ca}^{2+}$ & & & & & & 1.00 & -0.14 & 0.23 & 0.51 & 0.02 & 0.37 & 0.37 & 0.38 & 0.18 & 0.63 \\
\hline $\mathrm{Mg}^{2+}$ & & & & & & & 1.00 & 0.27 & 0.34 & -0.28 & -0.43 & 0.46 & 0.15 & 0.26 & -0.83 \\
\hline $\mathrm{Na}^{+}$ & & & & & & & & 1.00 & 0.39 & -0.30 & -0.01 & -0.22 & -0.01 & 0.42 & -0.04 \\
\hline $\mathrm{K}^{+}$ & & & & & & & & & 1.00 & -0.14 & 0.00 & 0.47 & -0.05 & 0.40 & -0.01 \\
\hline $\mathrm{Cl}^{-}$ & & & & & & & & & & 1.00 & 0.18 & -0.39 & -0.02 & -0.16 & 0.21 \\
\hline $\mathrm{SO}_{4}{ }^{2-}$ & & & & & & & & & & & 1.00 & -0.23 & 0.02 & -0.12 & 0.58 \\
\hline $\mathrm{HCO}_{3}^{-}$ & & & & & & & & & & & & 1.00 & 0.35 & 0.04 & -0.18 \\
\hline $\mathrm{F}$ & & & & & & & & & & & & & 1.00 & -0.02 & 0.10 \\
\hline $\mathrm{NO}_{3}{ }^{-}$ & & & & & & & & & & & & & & 1.00 & -0.09 \\
\hline $\mathrm{Ca}^{2+} / \mathrm{Mg}^{2+}$ & & & & & & & & & & & & & & & 1.00 \\
\hline
\end{tabular}

Correlation is significant at the 0.05 level (2-tailed), in bold.

Result of factor analysis of the groundwater chemistry indicates four factors (Table 4) that can be related to various controlling processes of hydrochemistry. These factors account for $76.90 \%$ of the total variance in the dataset. Factor I, which explains $28.86 \%$ of the total variance (Table 4), has a strong positive loading on $\mathrm{TH}, \mathrm{K}^{+}, \mathrm{Ca}^{2+}$ and $\mathrm{pH}$. This factor is designed as hardness controlled factor. The association of $\mathrm{TH}$ with $\mathrm{Ca}^{2+}$ and $\mathrm{K}^{+}$ and moderately with $\mathrm{HCO}_{3}{ }^{-}$shows that hardness is mainly caused by carbonate hardness. Factor II accounts for $26.77 \%$ of the total variance, which is characterized by strong positive loading of EC and TDS and negative loading of $\mathrm{Mg}^{2+}$. The negative loading of $\mathrm{Mg}^{2+}$ on factor II confirms that the concentration of magnesium in the groundwater does not contribute significantly to EC and TDS values (Table 3). The moderate loading of $\mathrm{Cl}^{-}$ and $\mathrm{SO}_{4}{ }^{2-}$ and the low loading of $\mathrm{Ca}^{2+}$ for factor II (Table 4) confirms their low contribution to EC and TDS values. Thus, factor II reflects the low mineralization of the groundwater, which is considered as salinity controlled factor. Factor III is characterized by high positive loading of $\mathrm{Na}^{+}(0.84)$ and $\mathrm{NO}_{3}{ }^{-}(0.78)$, with an account of $13.69 \%$ of the total variance. The nitrate derives mainly from the non-lithological sources ${ }^{16}$, which is caused by anthropogenic activities. For example, the association between $\mathrm{NO}_{3}{ }^{-}$and $\mathrm{Na}^{+}$ reflects the impact of domestic wastewater and septic tanks. Factor IV accounts for $7.58 \%$ of the total variance and is characterized by a strong positive loading of fluoride. The TA has a positive loading of 0.59 and $\mathrm{TH}$ has a very low positive loading (0.16). This suggests that the fluoride concentration in the groundwater is controlled by alkalinity and hence it is considered as alkalinity controlled factor ${ }^{17}$.

Cluster analysis was performed on the standardized dataset by Ward's method, using square Euclidean distance as similarity measure. Figure 2 presents the dendrogram with three clusters. Cluster I comprise the well water sites S and P1-P4. Cluster II shows well locations of P5-P7 and P9-P15. Cluster III has well sites of P8 and P16-P27. Summarized data of the clusters is shown in Table 5. 
Table 4. Varimax rotated factor loading matrix for wells water chemistry data in rainy season.

\begin{tabular}{ccccc}
\hline & \multicolumn{4}{c}{ Factor } \\
\cline { 2 - 5 } Variable & $\mathrm{F} \mathrm{1}$ & $\mathrm{F} 2$ & $\mathrm{~F} \mathrm{3}$ & $\mathrm{F} 4$ \\
\hline $\mathrm{pH}$ & $\mathbf{0 . 7 1}$ & 0.37 & -0.05 & -0.04 \\
$\mathrm{EC}$ & 0.12 & $\mathbf{0 . 9 2}$ & 0.15 & 0.20 \\
$\mathrm{TDS}$ & 0.13 & $\mathbf{0 . 9 2}$ & 0.15 & 0.18 \\
$\mathrm{TA}$ & 0.57 & -0.47 & -0.23 & 0.59 \\
$\mathrm{TH}$ & $\mathbf{0 . 8 4}$ & -0.06 & 0.41 & 0.16 \\
$\mathrm{Ca}^{2+}$ & $\mathbf{0 . 7 2}$ & 0.41 & 0.19 & 0.35 \\
$\mathrm{Mg}^{2+}$ & 0.07 & $\mathbf{- 0 . 7 7}$ & 0.29 & 0.25 \\
$\mathrm{Na}^{+}$ & 0.19 & -0.09 & $\mathbf{0 . 8 4}$ & -0.23 \\
$\mathrm{~K}^{+}$ & $\mathbf{0 . 7 7}$ & -0.20 & 0.33 & -0.01 \\
$\mathrm{Cl}^{-}$ & -0.23 & 0.56 & -0.22 & -0.05 \\
$\mathrm{SO}_{4}{ }^{2-}$ & 0.34 & 0.58 & -0.16 & -0.28 \\
$\mathrm{HCO}_{3}{ }^{-}$ & 0.57 & -0.47 & -0.23 & 0.59 \\
$\mathrm{~F}^{-}$ & 0.03 & 0.13 & 0.03 & $\mathbf{0 . 8 2}$ \\
$\mathrm{NO}_{3}{ }^{-}$ & 0.12 & -0.01 & $\mathbf{0 . 7 8}$ & 0.13 \\
\hline$\%$ Explained & 28.86 & 26.77 & 13.69 & 7.58 \\
variance & & & & \\
Cumulative & 28.86 & 55.63 & 69.32 & 76.90 \\
$\%$ of variance & & & & \\
\hline
\end{tabular}

$\%$ of variance

Absolute loading values $\geq 0.70$, in bold

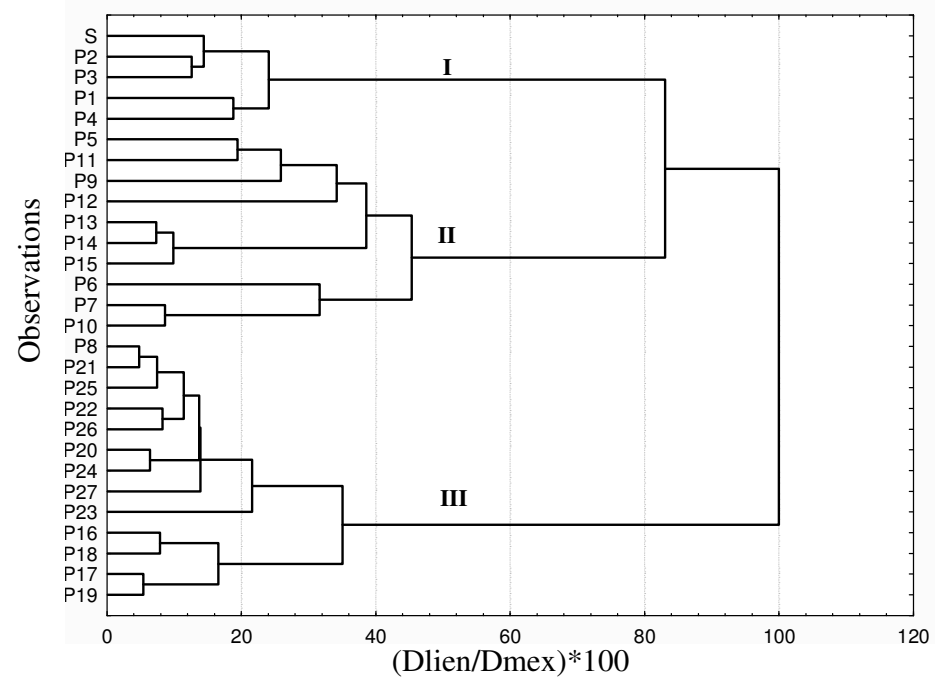

Figure 2. Ward's dendrogram of the groundwater samples.

In cluster I, the groundwater has low $\mathrm{pH}$ and $\mathrm{TH}$, and low concentration of calcium and potassium and high concentration of magnesium. The groundwater samples of Cluster II show high calcium concentration. The samples of cluster III are typical by their higher EC, $\mathrm{pH}$ values and the mean of the chloride concentration. Groundwater in the clusters I, II and III is characterized by $\mathrm{Mg}^{2+}>\mathrm{Na}^{+}>\mathrm{Ca}^{2+}>\mathrm{K}^{+}: \mathrm{HCO}_{3}{ }^{-}>\mathrm{Cl}^{-}>\mathrm{SO}_{4}{ }^{2-}>\mathrm{NO}_{3}{ }^{-}, \mathrm{Ca}^{2+}>\mathrm{Na}^{+}>$ $\mathrm{Mg}^{2+}>\mathrm{K}^{+}: \mathrm{HCO}_{3}{ }^{-}>\mathrm{Cl}^{-}>\mathrm{SO}_{4}{ }^{2-}>\mathrm{NO}_{3}{ }^{-}$and $\mathrm{Ca}^{2+}>\mathrm{Na}^{+}>\mathrm{Mg}^{2+}>\mathrm{K}^{+}: \mathrm{Cl}^{-}>\mathrm{HCO}_{3}{ }^{-}>\mathrm{SO}_{4}{ }^{2-}>$ 
$\mathrm{NO}_{3}{ }^{-}$facies, respectively. The importance of sodium and chloride concentrations in the chemical composition of the groundwater suggests the impact of domestic wastewater and septic tanks on the groundwater quality. The Student test applied on the groundwater parameters (Table 6) with $\left|\mathrm{t}_{\text {calculed }}\right|>\mathrm{t}$ observed has highlighted $\mathrm{pH}, \mathrm{EC}$, TDS, TA, TH, $\mathrm{Ca}^{2+}, \mathrm{Mg}^{2+}, \mathrm{K}^{+}$and $\mathrm{HCO}_{3}{ }^{-}$as discriminating parameters between Cluster I and Cluster II. Between the Clusters I and III, the discriminating parameters are $\mathrm{pH}$, EC, TDS, $\mathrm{Ca}^{2+}, \mathrm{Mg}^{2+}$ and $\mathrm{SO}_{4}{ }^{2-}$. The Cluster II differs to Cluster III by the discriminating parameters $\mathrm{TA}, \mathrm{TH}, \mathrm{Ca}^{2+}, \mathrm{Mg}^{2+}, \mathrm{K}^{+}, \mathrm{Cl}^{-}, \mathrm{SO}_{4}{ }^{2-}$ and $\mathrm{HCO}_{3}{ }^{-}$. Cluster analysis which is a complementary technique of statistical analysis to factor analysis has highlighted the same discriminating parameters except for sulfate ions.

Table 5. Summary statistics of the revealed clusters.

\begin{tabular}{cccc}
\hline Parameters & $\begin{array}{c}\text { Cluster I } \\
\text { Mean (Median) } \\
(\mathrm{n}=5)\end{array}$ & $\begin{array}{c}\text { Cluster II } \\
\text { Mean (Median) } \\
(\mathrm{n}=10)\end{array}$ & $\begin{array}{c}\text { Cluster III } \\
\text { Mean (Median) } \\
(\mathrm{n}=13)\end{array}$ \\
\hline $\mathrm{pH}$ & $4.26(4.00)$ & $5.49(5.57)$ & $5.39(5.60)$ \\
$\mathrm{EC}$ & $133.46(104.92)$ & $257.92(275.00)$ & $296.29(297.20)$ \\
$\mathrm{TDS}$ & $70.77(55.54)$ & $137.27(146.30)$ & $159.58(158.80)$ \\
$\mathrm{TA}$ & $19.00(15.00)$ & $49.19(50.00)$ & $11.31(12.00)$ \\
$\mathrm{TH}$ & $16.00(15.00)$ & $44.30(42.50)$ & $22.92(22.00)$ \\
$\mathrm{Ca}^{2+}$ & $7.60(8.00)$ & $20.70(20.50)$ & $15.69(16.00)$ \\
$\mathrm{Mg}^{2+}$ & $12.20(12.00)$ & $9.91(10.05)$ & $6.00(6.00)$ \\
$\mathrm{Na}^{+}$ & $11.35(9.81)$ & $13.54(8.92)$ & $8.49(8.05)$ \\
$\mathrm{K}^{+}$ & $3.64(3.20)$ & $7.30(7.60)$ & $4.36(4.10)$ \\
$\mathrm{Cl}^{-}$ & $20.42(19.53)$ & $15.31(15.04)$ & $23.96(26.00)$ \\
$\mathrm{SO}_{4}{ }^{2-}$ & $6.00(7.00)$ & $7.30(7.00)$ & $8.85(9.00)$ \\
$\mathrm{HCO}^{-}$ & $23.18(18.30)$ & $60.02(61.00)$ & $13.80(14.64)$ \\
$\mathrm{F}^{-}$ & $0.37(0.37)$ & $0.67(0.39)$ & $0.39(0.29)$ \\
$\mathrm{NO}_{3}^{-}$ & $1.29(0.66)$ & $3.34(1.00)$ & $0.94(0.84)$ \\
\hline
\end{tabular}

Table 6. Student test between clusters.

\begin{tabular}{|c|c|c|c|c|c|c|c|c|}
\hline \multicolumn{3}{|c|}{$\begin{array}{l}\text { Cluster I }(\mathrm{n}=5) \text { with } \\
\text { Cluster II }(\mathrm{n}=10)\end{array}$} & \multicolumn{3}{|c|}{$\begin{array}{l}\text { Cluster I }(\mathrm{n}=5) \text { with } \\
\text { Cluster III }(\mathrm{n}=13)\end{array}$} & \multicolumn{3}{|c|}{$\begin{array}{l}\text { Cluster II }(n=10) \text { with } \\
\text { Cluster III }(n=13)\end{array}$} \\
\hline Parameter & $\mathrm{t}_{\text {calculated }}$ & $\mathrm{t}_{\text {observed }}$ & Parameter & $\mathrm{t}_{\text {calculated }}$ & $\mathrm{t}_{\text {observed }}$ & Parameter & $\mathrm{t}_{\text {calculated }}$ & $\mathrm{t}_{\text {observed }}$ \\
\hline pH & $-4,340$ & & pH & $-3,339$ & & $\mathrm{pH}$ & 0,406 & \\
\hline EC & $-2,647$ & & EC & $-5,116$ & & $\mathrm{EC}$ & $-1,259$ & \\
\hline TDS & $-2,660$ & & TDS & $-5,280$ & & TDS & $-1,374$ & \\
\hline TA & $-2,690$ & & TA & 1,623 & & TA & 6,270 & \\
\hline TH & $-5,109$ & & $\mathrm{TH}$ & $-1,658$ & & TH & 6,201 & \\
\hline $\mathrm{Ca}^{2+}$ & $-4,871$ & & $\mathrm{Ca}^{2+}$ & $-7,085$ & & $\mathrm{Ca}^{2+}$ & 3,148 & \\
\hline $\mathrm{Mg}^{2+}$ & 2,429 & & $\mathbf{M g}^{2+}$ & 9,629 & & $\mathrm{Mg}^{2+}$ & 6,689 & \\
\hline $\mathrm{Na}^{+}$ & $-0,346$ & & $\mathrm{Na}^{+}$ & 1,043 & & $\mathrm{Na}^{+}$ & 1,323 & \\
\hline $\mathbf{K}^{+}$ & $-2,203$ & 2.160 & $\mathrm{~K}^{+}$ & $-1,542$ & 2.120 & $\mathbf{K}^{+}$ & 3,026 & 2.080 \\
\hline $\mathrm{Cl}^{-}$ & 1,320 & & $\mathrm{Cl}^{-}$ & $-0,724$ & & $\mathrm{Cl}^{-}$ & $-2,429$ & \\
\hline $\mathrm{SO}_{4}{ }^{2-}$ & $-0,979$ & & $\mathrm{SO}_{4}{ }^{2-}$ & $-2,575$ & & $\mathrm{SO}_{4}{ }^{2-}$ & 2,336 & \\
\hline $\mathrm{HCO}_{3}{ }^{-}$ & $-2,690$ & & $\mathrm{HCO}_{3}{ }^{-}$ & 1,622 & & $\mathrm{HCO}_{3}^{-}$ & 6,269 & \\
\hline $\mathrm{F}$ & $-0,783$ & & $\mathrm{~F}^{-}$ & $-0,164$ & & $\mathrm{~F}$ & 1,154 & \\
\hline $\mathrm{NO}_{3}^{-}$ & $-0,604$ & & $\mathrm{NO}_{3}^{-}$ & 0,744 & & $\mathrm{NO}_{3}^{-}$ & 1,809 & \\
\hline
\end{tabular}




\section{Conclusion}

In this study, aquifer materials are sandstone which contributes weakly to the groundwater composition. Two zones of wells water sites were identified from the $\mathrm{Ca}^{2+} / \mathrm{Mg}^{2+}$ ratio. The first zone with $\mathrm{Ca}^{2+} / \mathrm{Mg}^{2+}$ ratio less than 1 which indicates the weathering process of calcium minerals, the second zone with $\mathrm{Ca}^{2+} / \mathrm{Mg}^{2+}$ ratio higher than 1 which corresponds to the dissolution of more magnesium. Factor analysis identified four factors accounting for $76.90 \%$ of the total variance due to hardness, salinity, domestic waste water and septic tanks and alkalinity. Cluster analysis performed on groundwater parameters resulted in three clusters and the discriminating parameters highlighted from the Student test were in accordance, in majority, with those of factor analysis. In the absence of anthropogenic sources, the groundwater facies would be $\mathrm{Mg}-\mathrm{Ca}-\mathrm{HCO}_{3}$ in the cluster $\mathrm{I}$ and $\mathrm{Ca}-\mathrm{Mg}-\mathrm{HCO}_{3}$ in the clusters II and III as it is showed by the $\mathrm{Ca}^{2+} / \mathrm{Mg}^{2+}$ ratio. The study has helped to improve understanding of groundwater hydrochemistry of the area for appropriate management.

\section{Acknowledgment}

Authors are thankful to Prof. Subba Rao Nandipati, Department of Geology, Andhra University, for its suggestions in the preparation of the paper.

\section{References}

1. Public health Service. US Public Health Service Drinking Water Standards, PHS Publication \# 956, Government Printing Office, Washington, DC, 1962.

2. World Health Organization, Guidelines for drinking water quality-I, Recommandations, $2^{\text {nd }}$ Ed. Geneva WHO, 1993.

3. Subba Rao N, Prakasa Rao J, Nagamalleswara Rao B, Niranjan Babu P, Madusudhana Reddy P and Devadas D J, Curr Sci., 1998, 75(9), 887-888.

4. Gupta M K, Singh V, Rajwanshi P, Agarwal M, Rai K, Srivastava S, Srivastava R, snf Dass S, Environ Monit Assess., 1999, 59, 275-285.

5. Ravindra K and Garg V K, Int J Environ Health Res., 2006, 16, 163-166.

6. Standard Methods for the Examination of Water and Wastewater, 20 ${ }^{\text {th }}$ Ed. APHA, AWWA, WEF. Washington DC, 1998.

7. Malinowski E R, Factor Analysis in Chemistry, $2^{\text {nd }}$ Ed John Wiley \& Sons, New York, 2001.

8. Davis J C, Statistics and Data Analysis in Geology, John Wiley \& Sons. New York, 1986.

9. Kaiser H F, Educational and Psychological Measurement, 1960, 20, 141-151.

10. Everitt B, Landau S and Leese M, Clusters Analysis, $4^{\text {th }}$ Ed., Hodder Arnold, London, 2001.

11. Durfor C N and Becker E, US-Geological Survey Water Supply Paper 1812, 1964, p364.

12. Zhang Bo, Hong Mei, Zhao Yong Sheng, Liu Xueyu, Zhang Xuelin and Dong Jun, Environ Geochem Health, 2003, 25, 421-431.

13. Jain P, Sharma D J, Sohu D and Sharma P, Int J Environ Sci Tech., 2005, 2(4), 373-379

14. Saxena V K and Ahmed S, Environ Geol, 2001, 40(9), 1084-1087.

15. Tripathy S, Panigrahil M K and Kundu N, Environ Geochem Health, 2005, 27, 205-216.

16. Ritzi R W, Wright S L, Mann B and Chen M, Ground Water, 31, 221-229.

17. Al-Zarah A I, J Applied Sci., 2007, 7(23), 3669-3677. 


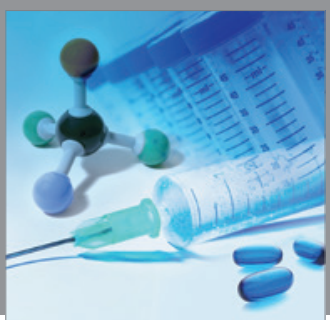

International Journal of

Medicinal Chemistry

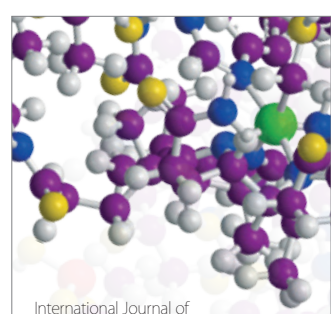

Carbohydrate Chemistry

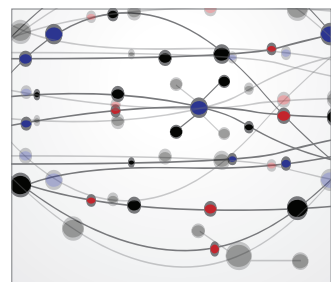

The Scientific World Journal
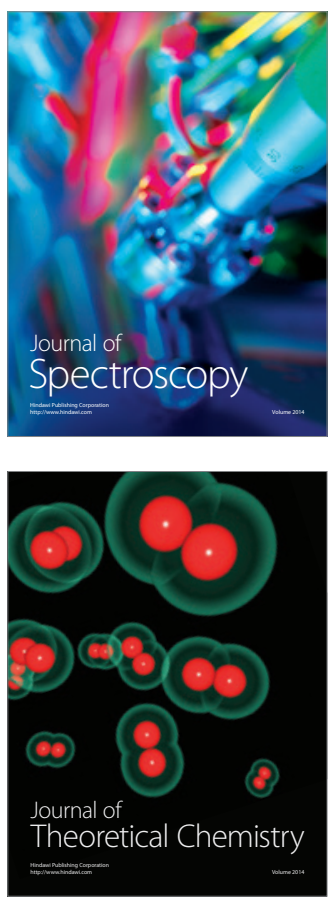
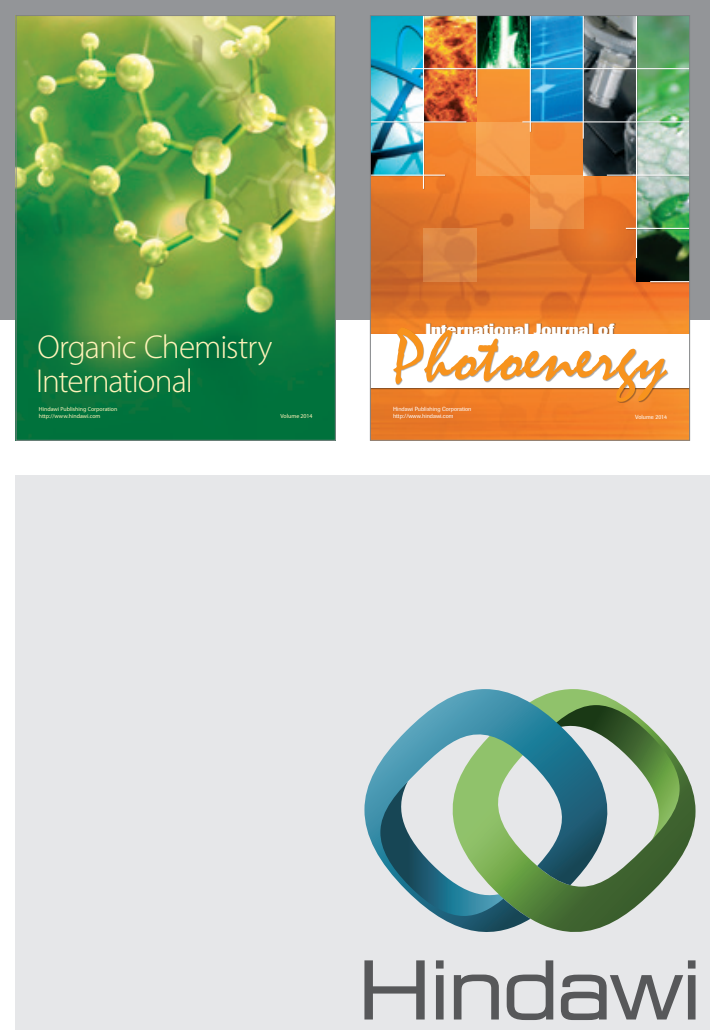

Submit your manuscripts at

http://www.hindawi.com
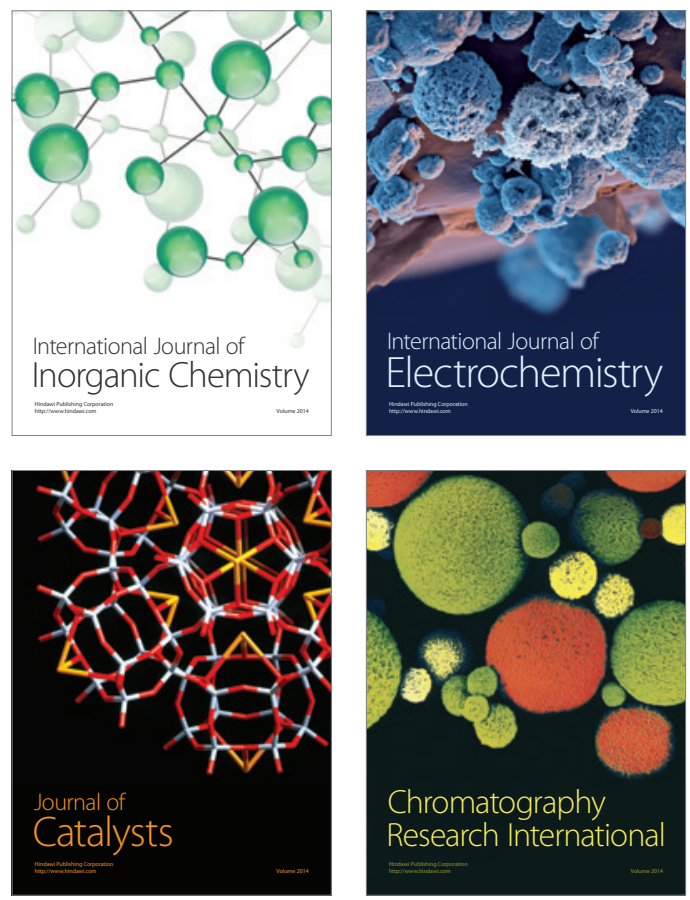
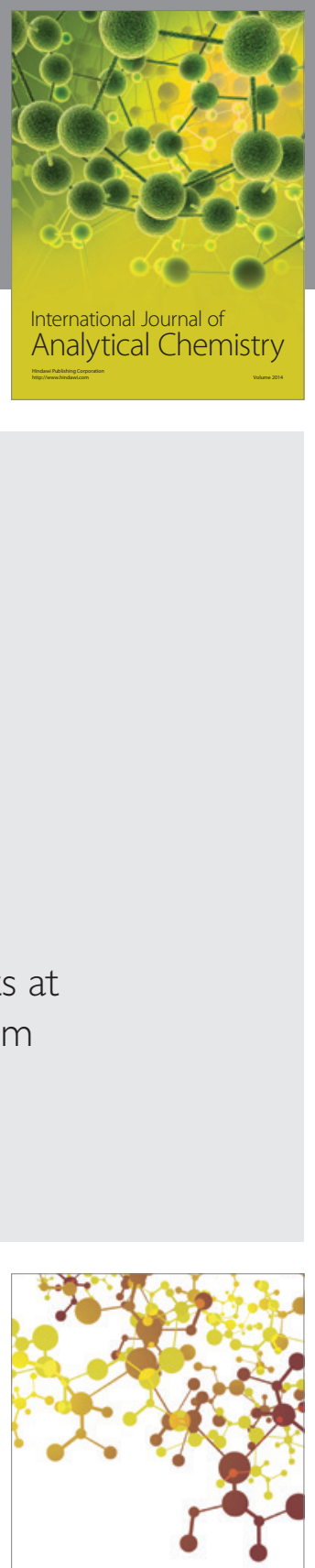

Journal of

Applied Chemistry
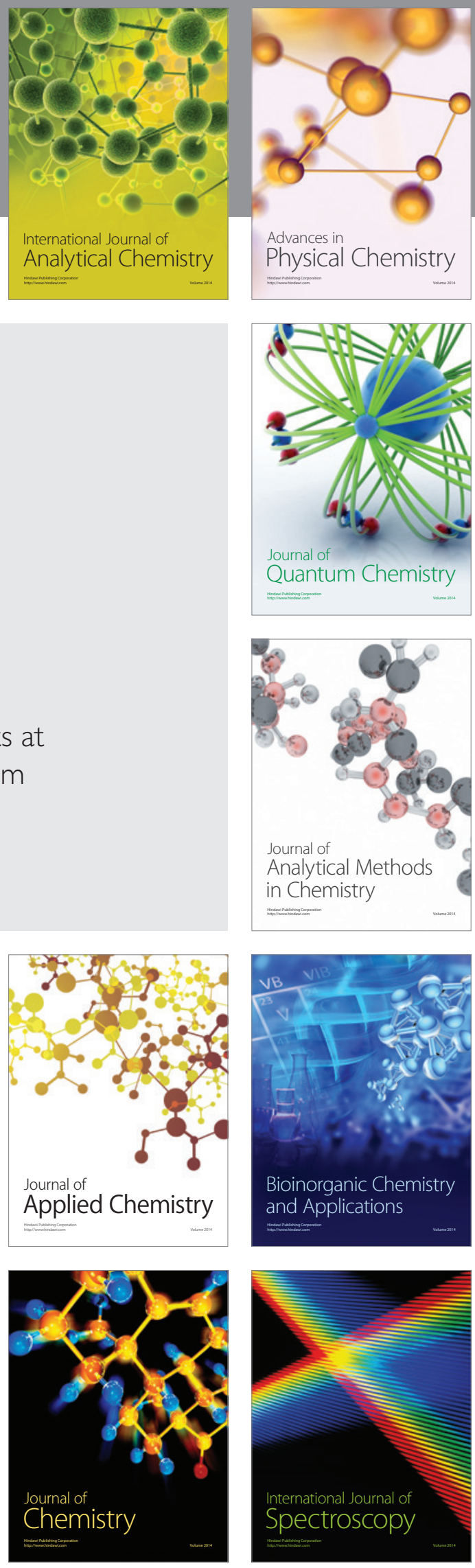